\title{
MedienPädagogik
}

Zeitschrift für Theorie und Praxis der Medienbildung

Special Issue Nr. 35:

Media literacy as intergenerational project: skills, norms, and mediation

Edited by Claudia Riesmeyer, Thorsten Naab,

Anne-Linda Camerini, Ruth Festl, and Christine Dallmann

\section{Mobile media practices of young people in "safely digital», «enthusiastically digital», and «postdigital» schools}

Annekatrin Bock and Felicitas Macgilchrist

\begin{abstract}
How do schools today engage with mobile media? Drawing on ethnographically oriented research at German Schools Abroad, this paper teases out three sets of practices regarding young people's mobile media use: "safe», "enthusiastic», and "postdigital». Presenting vignettes from three schools to illustrate each set of practices, the paper demonstrates how students are differently controlled, guided, and given space to shape their worlds through the practices. The paper highlights that these practices exist simultaneously. They enact different (not better or worse) institutional priorities and different (not better or worse) understandings of young people's mobile use. The paper also highlights the tensions when schools aim to control young people's mobile use, arguing that each set of practices undermines itself. It ends by reflecting on the implications for future research and practice if we see increased mobile media use in schools not, as often assumed, as a mark of «progress», «improvement» or «modernity», but instead as emerging from different understandings of school and young people.
\end{abstract}

Die Medienpraktiken von Jugendlichen in «geschützt-digitalen», «enthusiastischdigitalen» und «post-digitalen» Schulen

\section{Zusammenfassung}

Wie gehen Schulen gegenwärtig mit mobilen Medien um? Ausgehend von ethnografisch orientierter Feldforschung an Deutschen Auslandsschulen, arbeitet der Beitrag drei Muster schulischer Praktiken im Umgang mit der Smartphone-Nutzung von Jugendlichen heraus: "geschützt-digitale», «enthusiastisch-digitale» und "post-digitale» Praktiken. Anhand von Feldforschungsvignetten aus drei Schulen beschreibt der Beitrag die jeweiligen Muster anschaulich, um nachvollziehbar zu zeigen, wie unterschiedlich Schülerinnen und Schüler durch die Praktiken kontrolliert, geregelt oder befähigt werden, ihre Welt im Bildungskontext zu gestalten. Der Beitrag zeigt, dass die beschriebenen Praktiken gleichzeitig existieren. Sie setzen unterschiedliche (nicht bessere oder schlechtere) institutionelle Prioritäten und unterschiedliche (nicht bessere oder schlechtere) Verständnisse der Mediennutzung 
von Jugendlichen um. Der Beitrag macht die Spannungen sichtbar, die entstehen, wenn Schulen die Nutzung mobiler Medien von Kindern und Jugendlichen kontrollieren wollen und argumentiert, dass jedes Muster schulischer Praktiken sich selbst untergräbt. Der Beitrag endet mit einer Reflexion der Implikationen der Studienergebnisse für zukünftige Forschung und schulische Praktiken: Die zunehmende Nutzung mobiler Medien in der Schule ist nicht zwingend als Ausdruck von «Fortschritt», «Verbesserung» oder «Modernisierung» zu sehen, sondern wird vielmehr durch die unterschiedlichen Verständnisse von Schule und jungen Menschen hervorgebracht.

\section{Introduction}

Children and adolescents today arguably live in a «mediatized» world, spending their time «in» rather «with» media (Bird 2013; Couldry and Hepp 2017; Deuze, Blank, and Speers 2012). Their engagement with digital technology is, however, far more «varied and often unspectacular» «than the urban myth of digital natives» suggests (Kirschner and van Merriënboer 2013, 171; see also Boyd 2014; Selwyn 2009; Twenge 2018). In this media world, schools - as places where young people spend much of their waking lives - must also decide how to engage with mobile media, and how to encounter these varied and unspectacular media practices. This paper presents findings from ethnographically oriented fieldwork which explored how mobile media are being used in schools today. More specifically, drawing on an understanding of «discourse» as sociomaterial practice, the paper asks which discourses on mobile media are being enacted in schools, i.e. which configuration of sociotechnical imaginaries, infrastructural resources, institutional priorities, power relations, and understandings of the subject and sociality are being (re-)produced.

The paper observes three sets of practices in schools today: «safe», «enthusiastic», and "postdigital». It highlights marked differences among these three sets of practices: Students are differently policed, guided and given space to shape their worlds; they are introduced to entirely different perspectives on the powerful role of mobile media in today's world. After outlining relevant research, the paper sketches its methods and theoretical framing, before presenting the three sets of practices through vignettes from the field. It concludes with two reflections: First, on how each set of practices «backfires» to a certain extent, creating the conditions for its own subversion. Second, on the implications of these practices for popular models of technology integration in schools which posit a «development» from less to more use, or from «substitution» and «augmentation» to «modification» and «redefinition». In line with other ethnographic and critical approaches to education and technology, we argue that more - or more relaxed - use of mobile media in schools is not inherently a sign of progress or improvement. Instead, the findings illustrate how strongly school practices are connected to particular discourses about mobile media, with all the «messy» power relations such discourses entail. 
Children and Adolescents using mobile media in and out of school

The increasing digital media uptake by children and adolescents (Ito et al. 2013; O'Mara and Harris 2016; Ólafsson et al. 2014) has been accompanied by a large body of research that examines the rise of children's and adolescents' mobile phone use around the world (Feierabend, Plankenhorn, and Rathgeb 2017; Australia: Johnson and Oliver 2014; or Griffiths and William 2018; Tanzania: Joyce-Gibbons et al. 2018; Turkey: Nuray Zan 2015; or internationally: OECD 2015). More specifically, studies have turned their attention to the role of mobile phones in education (Keengwe, Schnellert, and Jonas 2014). While previous research on children's and adolescents' mobile phone use in education has tended to focus on the quantity of media use or the different uses of media in and out of school, this paper draws attention to the entanglement of practices and institutional setting.

Four contemporary strands of research are of particular interest for this paper: (1) developmental models of how to effectively integrate mobile media into education, (2) effects of mobile phone use in educational settings, (3) advantages/disadvantages of media use in the classroom, and (4) media practices.

1. Much popular writing on educational technology adopts a developmental approach to mobile media. Schools and educators that are hesitant to adopt technologies such as mobile media are criticized and encouraged to be more like those schools and educators that are (note the positively connotated words) «embracing» change, «freeing» themselves from the "constraints» of paper-based learning and achieving «digital normalization» (Lee and Broadie 2016). Well-known models such as SAMR (Puentedura 2012) describe possible uses of mobile media, including substitution, augmentation, modification, and redefinition, where the latter (modification and redefinition) are more positively valued than the former (substitution and augmentation). This literature reverberates on social media and in professional development workshops. It also echoes in research on teaching practices (e.g., McKnight et al. 2016). In the enthusiastic uptake of digital technology, there is little to no critical reflection on institutional contexts, the differing needs of teachers, students, learning, teaching, schools, or the legacies of inequitable educational policy.

2. A long tradition of quantitative research and large scale studies has investigated children's and adolescents' everyday, out-of-school media use (Bos et al. 2014; Feierabend, Plankenhorn, and Rathgeb 2017; Feierabend, Rathgeb, and Reutter 2018). This research is generally interested in the effects of mobile phone use in educational settings (Nuray Zan 2015; Griffiths and William 2018) with (quasi)experimental approaches identifying the potential for technology to improve learning outcomes (see for instance Sung, Chang, and Liu 2016; Wu et al. 2012). What these stimulus-response oriented studies cannot address is the complexity and messiness of everyday media practices. 
3. Turning more explicitly to the use of media are studies investigating the advantages and disadvantages of mobile phone use in the classroom. These have foregrounded two arguments. First, students are not as enthusiastic about mobile media use in school as is often assumed. In interviews, students express a desire for rules that regulate smartphone use in school, limit the time spent with devices in class, and disconnect personal and school use of apps (Friedrichs-Liesenkötter and Karsch 2018; Livingstone and Sefton-Green 2016). Second, particular schools, while not explicitly encouraging the educational use of mobile media in class, tend to restrict mobile media use and/or set specific rules about where and when «phones can be used». Many educators forbid mobile phones (Katz, Felix, and Gubernick 2014) or feel strongly that mobile phones should not be used in educational contexts, assuming it to be an «inappropriate tool for the classroom» or considering it to be «distracting and harmful» (Thomas and Muñoz 2016). These studies, however, have strongly focused on teachers' and students' perceptions of, and reflections on, likely usages in school (Thomas and Muñoz 2016; JoyceGibbons et al. 2018; Ott et al. 2018; Friedrichs-Liesenkötter and Karsch 2018), they have not yet aimed to observe actual ongoing media use and practices in school.

4. Most closely related to the approach of this paper are ethnographically informed studies interested in mobile phone practices in learning contexts (Pimmer 2016; O'Mara and Harris 2016). These studies tend not to investigate positive or negative «learning outcomes», but instead stress the complexity and uncertainty of sociotechnical practices in schools (Sims 2018; Breiter, Welling, and Schulz 2012; Wiesemann and Fürtig 2018). They investigate the complex disruptive/reproductive practices, identity work, and governance functions in which mobile media are entangled (Livingstone and Sefton-Green 2016; Selwyn et al. 2018). Studies have explored, for instance, transformations of traditional roles and power relations in formal education (Garcia 2012) or how mobile technologies serve as a cultural resource that young people use for meaning-making or for challenging classroom practices (Ranieri and Bruni 2013; Bock and Probst 2018). These studies have primarily examined schools which enact what we below call «enthusiastically digital» practices. Their findings could thus be interpreted, often against the authors' aims, as supporting the perspective in the first set of studies, cited above, that «more» digital is «better» or at least «inevitable» as schools reform and transform their practices. What is, however, happening in schools which take up digital technology in other ways? Which competing discourses on digital technology are being enacted in schools which are less enthusiastic?

Contributing to this emerging field of ethnographically informed studies, this paper takes an in-depth look at media practices in selected schools in order to explore how divergent discourse on mobile media is being enacted in schools. We pick up various 
strands of previous research by orienting our analysis not only to schools' infrastructure and overall approach to technology integration, but also to the way key educational actors imagine young people to «be», their imagined needs, desires and forms of sociality. Moreover, crucially, we orient to schools' institutional priorities.

\section{Theoretical and methodological underpinnings}

We look at school as a public space where young people spend much of their waking lives. We focus on «media practices» - not learning - with an understanding of practices in line with practice theories as those routinized types of material, bodily, mental, affective, technological, tactical, social, unbounded, mundane and often inadvertent behavior in which media are entangled in today's sociotechnical everyday (Schatzki 2008). We understand «discourse» not simply as speech and writing, but as systems of signification that include institutions, infrastructure, and other forms of materiality (Wrana and Langer 2007; Laclau and Mouffe 1985). With an approach to «discourse ethnography» or «ethnographic discourse analysis» (Macgilchrist and Van Hout 2011; Krzyżanowski 2011), we are thus interested in observing how discourse is enacted through sociomaterial practices, i.e., the norms, common-sense understandings, power relations and ideas of the subject and sociality that emerge when sociotechnical imaginaries are enacted in the school (drawing on, e.g., Jasanoff and Kim 2015; Haraway 1991). Focusing analytical attention on the enacting of discourse through practices enables us to tease out surprising, unexpected or inexplicable «rich points», ruptures and ambivalences in the data (Macgilchrist, Ott, and Langer 2014; Agar 2006).

This paper draws on data generated in two research projects (2016 - 2018), which observed young people's media practices in nine German Schools Abroad (DAS): in Africa, Asia, Europe, North America, and South America. DAS are international schools that orient to German curricula and are part of a network of schools that shares equivalent educational, structures, routines, institutional frames, rules, and agents. ${ }^{1}$ An interdisciplinary team of eight researchers collected field data from September to December 2016 and June to December 2017. The fieldwork was comprised of three-week research stays, with one researcher at each school. Each researcher conducted classroom observations, interviewed school leaders, teachers, librarians, and edtech coaches (individuals employed to keep up to date on new educational technology [edtech] developments, and to provide in-service teacher training) and led group discussions with students.

1 For more information on the German Schools Abroad system, and the two research projects, see (SzakácsBehling et al. 2020) and the project blogs: http://digitale-medien-und-deutsche-auslandsschulen.gei.de, http://globaldas.gei.de. These schools are well-resourced schools, partially private and partially statefunded. We draw on these schools in this paper not to make specific argument about German Schools Abroad but to highlight patterns which resonate more broadly with different forms of formal schooling. 
We collected, analyzed, and interpreted our data as a team through a focused ethnographic approach. Understanding data collection as an «iterative, recursive and abductive» practice, this orients to the processual character of data interpretation (see also Agar 2006). During fieldwork the team met via digital technologies, constantly reflecting and problematizing the researchers' roles, their positionality and their co-producing role in interpreting the data (Bartlett and Vavrus 2017; Bikker et al. 2017; Burawoy 2003).

"Thus, comparison was enabled from an early stage of research and continued throughout via critical exploration of moments of surprise - known as 'rich points' (Agar 2006) discussed within the team, allowing for productive possibilities of irritation and disruption.» (Szakács-Behling et al. 2020).

To explore the discourses on mobile media that are being enacted in schools, this paper selects «vignettes» from three focal schools (Mohn and Amann 2006). Although no school could ever coherently enact only one discourse, each school we observed had a tendency towards one discourse. In line with ethnographic and discourse-analytical epistemologies, our goal here is not to describe a typology or identify prototypes, but to present compelling in-depth accounts of situated practices. The vignettes do not aim to support a model or a claim to universal truth. Instead, they aim to be recognizable and to resonate with other schools in other locations.

\section{Vignettes from the case study schools}

\section{(1) «Safely digital» practices}

Three observations from what we will call the Purple School (pseudonym) illustrate the first set of practices identified in this research. In the first, the school's headteacher explains the school policy of banning mobile phone use during the day; in the second, we collate a series of classroom practices; in the third, students tell us about their subversion of the policy.

In an interview, the headteacher describes the new policy:

«We had a policy up to last year where they were allowed to use their phones during break time. [...] But last year, [...] I noticed they weren't talking to each other. They were all on a device; they were all playing games, that was one aspect of it. The other aspect was that sometimes issues that were arising outside of school through social media were coming into the school environment. And they were proliferating around the school community through the mobile phone. Not that the kids were sending things, but that they were showing things on them. And so we decided, no, this has got to be a safe environment for kids and at least there is a zone whereby nothing/ or there is a time of the 
day from 8:15 in the morning until 4:15 in the evening, when they finish, nothing is sent. Nothing comes in. Or they're not aware of it, you know? And that it's a zone, a mobile-free zone or a device-free zone for that time.»

The headteacher reflects on how bullying has changed with the widespread use of mobile phones:

«And fear is the impact that they have outside of school because you can't control it. And they can be devastated, you know? For children who are particularly vulnerable, you know, to that kind of behavior, they have no respite. There is no time which is not happening to them. When I was growing up, you know, bullying was somebody calling you names, but when you went home that was it, you know? You were safe. Now, there is no respite; there is no time at which you cannot be affected by it. And that to me is very concerning, you know? And it is there, and we have limited control over it outside of the school. But we can control it here. And that's what we say, once it begins to encroach on the school environment, then we will act. And it was/ I expected greater resistance when we introduced that policy.»

In fact, parents were very supportive of the new policy banning mobile phones, and the student council only voiced limited displeasure. The head continues:

«But, you know, it is one way of us protecting them in here from all of the, I suppose, the unpleasant stuff that happens on social media, you know, that they have or may have to deal with, you know?»

These extracts illustrate the keywords that produce a discourse of safety, protection, and control. Students here need a «safe environment», where they can - for a time have «respite» from social media. They need to be «protected» from «the unpleasant stuff that happens on social media». A «mobile-free zone» or «device-free zone» is the school's response to these perceived needs.

During the fieldwork, this discourse was enacted in classroom practice. We observed, for instance, official posters warning about cyberbullying, and of a project week dedicated to cyberbullying, which included informational events on bullying, and project work designing posters. There were professional development courses for teachers on ensuring well-being for teachers and students, and on dealing with online violence. Moreover, we observed a discussion in the Philosophy class on ethical online behavior and ethical interactions in WhatsApp peer groups. The schoolwide policy is enacted in pedagogical choices which prioritize school control, safe zones, and a protective approach to students' (and teachers') perceived needs.

Students, however, unsurprisingly, exhibited behavior which contravened the formalized school policy. They did not simply put their phones away at 8:15 am and retrieve them at 4:15 pm. Instead, they developed hidden ways of using their mobile phones to break the rules. In an informal chat on the way to the interview room, when the interviewer took out her phone to check the time, the students told her 
how they smuggle their phones into the school toilets to check WhatsApp and the push notifications from their social media accounts to remain up-to-date on what is happening outside the "safe environment» the school aims to create. As generations of students before them, they use the classic space within the school building (the toilets) to maneuver themselves beyond the school's control; but they update these practices of escaping control to our current media age.

These three sets of observations from the Purple School highlight this particular school's approach to developing and enforcing a school-wide ban on mobile devices during school hours. We believe they will resonate with a broad range of other schools in Germany (and possibly beyond Germany). ${ }^{2}$ The school practices enact several dimensions of the discourse of safety, protection, and control:

First, the school's infrastructure and approach to technology integration: These schools are likely to have interactive whiteboards and projectors that enable the teachers to continue traditional teaching practices in a digitally assisted teaching scenario. They are less likely to introduce 1:1 models, since requiring each student to have a tablet or notebook would thwart attempts to create a safe, device-free zone.

Second, the view of young people: In this scenario, students are seen as vulnerable, at-risk, and in need of protection by adults (see Craft 2011). Since students are thus considered less capable of making decisions about their own mobile media use, teachers, administrators, and school leaders decide what is «good» or «bad» media use (see Sims 2014). Quality peer communication is seen as face-to-face interaction. Losing that face-to-face communication is seen as detrimental to students.

Third, institutional priorities: These schools enact an understanding of formal education as protective of young people. It should create a cocoon, a safe environment where students can find respite from pressures outside the school walls. Even if not all students are vulnerable to cyberbullying, the school sees its role as caring for the most vulnerable. It does this by controlling and regulating media use. Schools, in this understanding, are responsible for setting and enforcing coherent school-wide policies regulating media practices. Networked connections to spaces beyond the school boundaries are seen as risky. Mobile devices signal uncontrolled, unfiltered, potentially inappropriate practices. Although not observed at the schools in our fieldwork, there is space here for a related discussion of the role of schools in protecting young people from their exploitation by technology corporations primarily interested in harvesting data (see Watters 2017; Williamson 2018). This «data care» is institutionalized across schools in Germany, with broad awareness of the implications of using Google products for student privacy.

2 Further research that we are currently conducting on media practices in schools supports our assumption that this school is not an isolated instance, but an illustration of how one discourse on mobile devices is enacted in schools. Each school, of course, enacts the discourse in its idiosyncratic way, blending it with other discourses. 
Fourth, ruptures: The observations demonstrate, however, how the policy «backfires» in practice. Not all students see themselves as vulnerable and in need of protection. They enact themselves as agentic and capable of controlling their own mobile and communicative practices. By finding zones in which they can use prohibited devices privately, they subvert attempts to regulate their online communication.

\section{(2) «Enthusiastically digital» practices}

In the second school we present here, the Yellow School, we experienced an atmosphere of enthusiastic support for, and celebration of, the possibilities of using mobile media during the fieldwork. This school has been thinking about introducing novel technology for about the same length of time as the Purple School but has made significantly different decisions about what and how to integrate mobile media into school life. As above, three sets of observations ground our account of «enthusiastically digital» practices. In the first, we summarize teachers' accounts of the advantages of working with new technologies. In the second, we describe three parallel classroom situations. In the third, we report, as above, on students' subversive use of digital technology to achieve their goals.

In interviews, teachers mentioned a host of advantages of working with the new technologies. They particularly enjoyed the new possibilities of sharing work with their colleagues. The school had developed a very open mode of collecting and making available lesson plans across the subjects. They listed the benefits for novel group communication practices, creative and collaborative ways of working together and using mobile phone apps, e.g., a calculator or language apps, as learning tools in the classroom. One teacher stressed the opportunities for digital participation by using mobile media:

«I see a great opportunity in this. In the availability of the same information, at any time; that everyone can inform themselves on anything and accordingly make an informed decision themselves."

In these examples, teachers' enthusiasm for mobile media arises from two primary functions of the media: as «tools» for digital education and as «sources» for gaining information.

These priorities enact an enthusiastically instrumental discourse (not in a negative sense, but in the sense of technology being instrumental to achieving educational success). Mobile media here are novel «instruments» to help solve a host of pedagogical challenges. Many of the goals reflect the classic aims of progressive educational reform movements, i.e., empowering students, encouraging their independence, facilitating collaboration, critical thinking, creativity, and a love of learning. Mobile media are seen as technological tools to support these pedagogical goals. 
Individual teachers had leeway in the Yellow School to decide when and how they wanted to use which (old or new) technology. Most of the classrooms had an interactive whiteboard; each student had a tablet (iPad). We observed, for instance, students working in three German classes. In one, the teacher worked with the blackboard, starting her lesson with a paper-pencil Hangman game. The game was the analogue «opening» for the lessons' exercise that introduced the students to QR-Codes. In the second class, the teacher started the lesson with a quiz and used a shared Google Classroom document to collect the students' answers. In the third class, the teacher explained to the students that they were going to make a news clip with their iPads. Previously, she had asked classes to write a newspaper text. This year, with the iPads, they emulated the TV news instead.

There was no school-wide policy mandating that teachers should use technological tools. Teachers could decide the pedagogical benefit on a case-by-case basis. What becomes clear, however, is that across the fieldwork, it was consistently the teachers who decided which media to use for which specific task. Students were, in a sense, consumers of their teachers' decisions.

Students did, however, also subvert the enthusiastically instrumental orientation to mobile media. They subverted the generally teacher-led approach to media use in classrooms, for instance, by suggesting to teachers how their iPads could be integrated more seamlessly into tasks. In one case, students took out their phones in the history lesson to take photos of what the teacher wrote on the blackboard, though he explicitly asked the students to write down the final remarks of the lesson by hand. This teacher admitted to us in an interview that he also knows that the students secretly forward the photos, and that he is still undecided whether to support these practices or to forbid them. In another case, the students explicitly requested their teacher to upload the assignments and classroom notes to the school cloud. The teacher was initially skeptical about the purchase of doing this but was then pleasantly surprised at how well it worked and how enthusiastically the students used the notes to prepare classroom lessons and tests. A moment that young people may not have parsed as «subversive» but which we noted with interest arose during a group discussion: When asked if anything had changed in the roles of students and teachers since getting individual iPads, students responded:

Student 1: «Yeah. That's more like, the teacher is more like the helper. And not the one who says it is done this way and that way and the only source of information, because if the teacher says something and nothing else, then you have to believe him. Whether it's right or not because you don't know. But then, when you have iPads, and so on, the teacher is not just your source of information, he helps you and gives you information on the side and he explains that.» (Girl, 13 years old) 
Student2: "Or you can explain things to him if you know more information about it.» (Girl, 13 years old)

Students reflect on how the teacher shifts from being the singular source of information in the classroom to being an «assistant» (a «helper»), facilitating their knowledge acquisition. Moreover, the students begin to explain things to the teacher, i.e., it is clear that they sometimes know more than the teacher does. These shifting roles arguably unsettle the traditional knowledge hierarchies of formal schooling.

As above, these observations highlight one particular school's approach to mobile media, which potentially resonate with other schools today. The practices enact several dimensions of the enthusiastically instrumental discourse:

First, the school's infrastructure and approach to technology integration: These schools aim to secure funding in order to ensure that the basic infrastructure (hardware, software, connectivity) is available to all teachers who plan to use it. If possible, these schools employ dedicated IT admins or use decentralized IT support systems. While school leaders often express a desire for all teachers to use mobile media as much as possible, they acknowledge individual differences and the need to respect teachers' autonomy and professionalism. A teacher's motivation, inspiration, and experiences determine the extent to which he or she will use mobile media. Overall, rather than foregrounding anxiety, here, technology is embraced as «exciting and enabling» (Craft 2011, xvii), as a way of improving schooling.

Second, the view of young people: This approach acknowledges that young people live «in» media. It aims to connect with young people's everyday lived experience in order to make the most of their interests and informal capacities in learning contexts. Young people are seen as differentially capable of engaging critically, creatively, collaboratively, and independently with mobile media and networked connections beyond the school. Teachers, however, still make decisions for young people in schools. The goal is to foster their capacity to use technology as a tool to achieve legitimized ends (e.g., learning, critical thinking, collaboration, media production; not playing).

Third, institutional priorities: The priorities of these schools map well to the priorities of educational policy-makers today, and to the vibrant online communities advocating innovative forms of digital education, including such disparate sites as, e.g., EdSurge, global edtech conferences, or Twitter (e.g., \#twitterlehrerzimmer, \#edtechchat). The institution aims to prioritize the pedagogical ('Primat des Pädagogischen', e.g., KMK 2016, 9) rather than blindly purchase and use digital technology simply because of a "coolness factor» or its status as new technology. Mobile media are, in this sense, folded into pedagogical principles, i.e., teacherly decisions. Teachers and other adults are seen as curators of the media which young people should use during the school day. Since the institution of formal schooling prioritizes learning and educational success, mobile media are primarily used as instruments to achieve 
these goals. Although student-led activities are desirable within this enthusiastically instrumental discourse, these tend to be embedded within the institutional requirements of formal education, similar to policy discourses on education in a digital world (KMK 2016, Macgilchrist 2017).

Fourth, ruptures: Students generally welcome innovative, productive, motivating use of mobile media, such as collaborative writing and making news clips. Some acknowledge matter-of-factly their subversion of traditional power hierarchies when they explain their superior knowledge of a topic to their teacher. Although the role of teacher-as-facilitator is lauded as a transformative goal of progressive education, it arguably remains quite unusual (and perhaps disorienting) for many teachers today.

\section{(3) «Postdigital» practices}

The third set of observations stem from the Blue School, a school which has been using laptops and other mobile devices for almost 20 years. The school is very wellresourced. During the fieldwork, Grades 5 and 6 were working with Surfaces. The school employs several «edtech coaches» who are responsible for keeping up to date on new hardware and software. They inform and support teachers, project work, and students. The observations in this section focus first on young people and adults discussing the ambivalences of mobile media in school; second, on activities we observed during the school day; and third, on a teacher-librarian reflecting on how technology can (or cannot) help transform formal education.

In extensive group discussions, young people talked about how they engage with mobile media during their school day. Their comments were balanced and nuanced. They reflected on how some of them prefer to learn with the laptop or on paper, with one student noting that he finds studying with the laptop strange because it is so easy to get distracted. Another student comments that she used to print out documents from Moodle to study with them, but since they use OneNote more often, and it is very difficult to print, it is easier to work with those materials on the laptop. How one prefers to study, she reflects, is a matter of taste.

Reflecting on the changes to student and teacher roles when students now may know more about a specific issue than teachers if they have accessed information online (see Yellow School above), these students continue the discussion by reflecting on the need to nevertheless align their answers to what the teacher thinks is the right answer, because "the teacher grades you». The students discuss several teachers who insist they are right, despite students' questioning. In these cases, the students take the teacher's position despite their conviction that the information they found online was more accurate than the teacher's position. They also mention one teacher, in Sports Science, who was prompted by the students to do some more research on the topic himself and changed his mind, agreeing that the students had found valuable new information. 
The school librarian reflected on the role of education in the post-industrial future. Since so many middle-class jobs are going to be replaced by technology, she says, we need to rethink what school is about:

«We need to stop making students feel stupid and start making them feel clever. The reverse («das Umgekehrte») of what school has been. [...] Of course, they are digital natives, but they still need a lot of interpersonal skills. They need to know how to use their time sensibly («sinnvoll») and they need to be able to interact humanely («intermenschlich agieren»). [...] And that is, of course, a contradiction, because we do that with technology. We defamiliarize, yes, and somehow find a balance».

In each of these observations, technology is tied up in ambivalences, contradictions, and forms of sociality. Our interview questions asked about «digital» technology and «digital» practices, but the answers invariably folded «the digital» into multi-faceted sociotechnical configurations, far more so than the other schools. Unlike the Purple and Yellow Schools, for the Blue School, the digital is not at the forefront of attention. Instead, these students and librarian are producing what could be called a "postdigital» discourse on mobile media. The "post» highlights the backgrounding of digital technology in these schools (Jandrić et al. 2019; Macgilchrist 2019; Taffel 2016). Here all sorts of media (mobile devices, apps, clouds, paper, pencils, 3D printers) live alongside one another. «Postdigital schools» do not draw mobile media into the rhetoric of progress, novelty, and innovation.

This postdigital configuration was also enacted in school activities we observed throughout the fieldwork. Young people hand out flyers with the QR code for a podcast they had made for Pink T-Shirt day (on cyberbullying, a topic they had chosen). In the school's Digital Technology Lab, students document their progress on OneNote as they use CAD software to design storage items they then physically build. A class turns off all the lights, projectors, computers in their classroom so that the teacher can read aloud a Christmas story (from his iPad, so he needs no light), creating a warm and cozy auditory experience. Students co-author a story using collaborative writing tools. It is set in the past, and when one student includes a phone call in the story, two fellow students whisper together, check on Wikipedia and then raise their hands to say that phones had not yet been invented in that period. Students in a German class finish their task, the teacher opens one of the students' documents on the interactive whiteboard and reads it aloud. Picking up on one issue from the text, she writes some modal verbs on the blackboard; the class discusses modal verbs for a while. In each of these instances, various technologies from various «ages» are woven together to inform passers-by, craft an object, create an atmosphere, co-create a story, or learn grammar. 
What happens to schooling in this postdigital configuration? Innovation is a word often used in relation to technology. We asked teachers in each school what «innovation» meant to them. Whereas in other schools, they usually replied by noting specific technologies, teachers in the Blue school reflected more broadly. One, for instance, said that innovation for him means «first of all a certain amount of thinking otherwise» («Querdenken und Andersdenken»). He compared the school structure, which remains fairly teacher-centered, even in the most innovative of moments, and the 45-minute classes, where a radical change is to move to 90-minute cycles:

«Yes, of course, we are innovative when it comes to digital media. You get there, at least in the average of what can be done, I think this school is very, very far. But to think school as a whole innovatively, as an overall model in its structures, in its togetherness, in what we actually want, what we actually are, that is where we are still very far from, even abroad.»

The teacher from the cited interview was interested in structural change, and in getting students more involved in their learning. He was excited by transformative models such as in a Swedish school he had heard of, where students no longer have regular subject-specific classes, but work on larger scale projects and seek out the specific knowledge as they need it. Ironically, the school's design lab that won a prize for innovation could rarely be used by students in the higher years. They had no time. They had to fulfill the requirements of the formal curricula.

The schools in which we observed postdigital practices had longer histories of working with digital technology than the protective or enthusiastic schools. Mobile media were no longer new and disruptive, but part of the everyday. Returning to the dimensions noted above:

First, the school's infrastructure and approach to technology integration: These schools integrate mobile media into teaching and learning routines and «build» classrooms that are open to mobile media use, for example by connecting different devices, allowing unrestricted WiFi access, and making personnel available as edtech coaches. Different technologies are given equal weight, from pencil to 2 -in-1 device; from interactive whiteboard to blackboard.

Second, the view of young people: Is more difficult to pin down in this third approach. Some teachers espouse the classic hierarchy of knowledge, whereas other teachers are more likely to take their own learning forward by following up on information that students have found online. Cyberbullying is still an issue that crops up, but students are also given free reign of their mobile devices. There is little policing in classes of what students might be doing on their devices. In turn, students express nuanced reflections on which kind of technology (paper or mobile device) is better for which kinds of tasks. They show a keen awareness of the potential for distraction. 
Third, institutional priorities: The priority lies on innovative forms of learning, on using appropriate technology (light switches, collaborative tools, podcasts, design labs, chalk) to make learning interesting and meaningful. Students shape, to a certain extent, how they use mobile media throughout their school day.

Fourth, ruptures: But precisely herein lies the main rupture we noticed at postdigital schools, highlighted by the teacher above: Innovation stands at the forefront of attention, and innovation can certainly be seen in small changes in these schools, but school structures are not fundamentally transformed. Young people shape some of their own media use throughout the day. However, they also remain firmly positioned within the temporal and informational modes of traditional, formal, legitimized state curricula. These more fundamental transformations can be aided by the ease of using mobile media, but they are largely based on pedagogical/policy/political decisions that are independent of technology.

\section{Concluding thoughts}

Exploring how discourses on mobile media are being enacted in schools, this paper has teased out three bundles of school-based mobile media practices. Although no school will enact a single unified approach to mobile media, we observed shared repertoires in each school, i.e., a shared school culture of engaging with mobile media. The paper presents vignettes from three focal schools, suggesting that the practices in these schools are recognizable in other secondary level schools in the German school system, and potentially beyond: (1) «Safely digital» practices enact a discourse of safety, protection, and control. They limit the use of mobile devices to create a safe environment for students. (2) «Enthusiastically digital» practices enact a discourse of innovation and novelty. They integrate new (often mobile) media to support students' creativity, critical thinking, and collaborative communication practices and to achieve teacherly objectives. (3) «Postdigital» practices enact a discourse of techno-ambivalence, backgrounding «the digital», and foregrounding the sociality of schooling and the contradictions of focusing on mobile media as a solution. They use divergent media for divergent purposes, without being too concerned or too enthusiastic about any particular medium (old or new; static or mobile). «Innovation» in postdigital schools does not refer to technology integration, but to fundamentally transforming the institutional structures of formal schooling.

Further research could explore the extent to which these three sets of practices resonate more widely in other schools, paying more attention to the contexts of each school, and the extent to which discourses of risk, creativity, student-centeredness, data care, etc. are circulating and/or have become common-sensical. In addition, to understand more fully how mobile media can be used in schools, e.g., for digital literacy, subject-specific teaching, or project work, we need further research that relates students' out-of-school mobile media practices to in-school practices. 
We end this paper with two reflections. First, on how each set of practices provides the «seeds of its own subversion» (Hepburn 1999, 641): The stated goal of a "safely digital» school is to create a safe environment by minimizing mobile media use. Yet students find ways to confound this, such as taking their mobile phones to the toilets. By prohibiting mobile phone use, the school closes the space to openly discuss and reflect on how students can best engage safely with mobile devices. The ostensible goal of «enthusiastically digital» schools is to embrace the transformational pedagogies and possibilities of the digital. Yet teachers remain the decisionmakers, deciding which kinds of (mobile) activities students will do, and thus undermining a core goal of transformative pedagogies that students take charge of their own learning. In «postdigital» schools, transformational innovation stalls precisely because mobile media are not drawn into the rhetoric of progress, novelty, and innovation. Schooling is still regulated from the top down and remains fairly teacherled, fulfilling formalized state curricula. Although technology is no longer seen as a means of overcoming the institutional constraints of schooling, nothing has replaced technology's utopian promise.

Our second reflection turns to the implications of these findings for popular models of integrating technology in schools. Overall, the vignettes support critical arguments about the inability of institutional or teacherly decisions to determine, plan, restrain, or orient young people's mobile media use. The effects of policies on technology use are invariably indeterminate and indeterminable in practice. The difference between a cautious uptake of mobile media is not, as is often assumed (in policy, practice, and scholarship), a developmental step «behind» more widespread or faster uptake of media. Instead, each approach to mobile media enacts a societal discourse on mobile media. The practices exist contemporaneously; they are the enactments of differing (not incremental) discourses.

\section{References}

Agar, Michael. 2006. «An Ethnography By Any Other Name ...» Forum Qualitative Sozialforschung / Forum: Qualitative Social Research Vol 7 (September): No 4 (2006): Qualitative Research in Ibero America. https://doi.org/10.17169/fqs-7.4.177.

Bartlett, Lesley, and Frances Katherine Vavrus. 2017. Rethinking Case Study Research: A Comparative Approach. New York: Routledge, Taylor \& Francis Group.

Bikker, A.P., H. Atherton, H. Brant, T. Porqueddu, J.L. Campbell, A. Gibson, B. McKinstry, C. Salisbury, and S. Ziebland. 2017. "Conducting a Team-Based Multi-Sited Focused Ethnography in Primary Care». BMC Medical Research Methodology 17 (1). https://doi.org/10.1186/ s12874-017-0422-5.

Bird, S. Elizabeth. 2013. The Audience in Everyday Life: Living in a Media World. 1st ed. London: Routledge. https://doi.org/10.4324/9780203954225. 
Bock, Annekatrin, and Larissa Probst. 2018. "Opening up the Classroom: Enabling and Interrupting Digital Media Practices in School». Education in the North 25 (3): 130-38.

Bos, Wilfried, Birgit Eickelmann, Julia Gerick, Frank Goldhammer, Heike Schaumburg, Knut Schwippert, Martin Senkbeil, Renate Schulz-Zander, and Heike Wendt, eds. 2014. ICILS 2013: computer- und informationsbezogene Kompetenzen von Schülerinnen und Schülern in der 8. Jahrgangsstufe im internationalen Vergleich. Münster: Waxmann.

Boyd, Danah. 2014. It's Complicated: The Social Lives of Networked Teens. 1. Aufl. New Haven: Yale University press.

Breiter, Andreas, Stefan Welling, and Arne Hendrik Schulz. 2012. «Mediatisierung schulischer Organisationskulturen». In Mediatisierte Welten, edited by Friedrich Krotz and Andreas Hepp. Wiesbaden: VS Verlag für Sozialwissenschaften. https://doi.org/10.1007/978-3-53194332-9.

Burawoy, Michael. 2003. «Revisits: An Outline of a Theory of Reflexive Ethnography». American Sociological Review 68 (5): 645. https://doi.org/10.2307/1519757.

Couldry, Nick, and Andreas Hepp. 2017. The Mediated Construction of Reality. Cambridge, UK ; Malden, MA: Polity Press.

Craft, Anna. 2011. Creativity and Education Futures: Learning in a Digital Age. Stoke-on-Trent: Trentham.

Deuze, Mark, Peter Blank, and Laura Speers. 2012. «A Life Lived in Media». Digital Humanities Quarterly 006 (1).

Feierabend, Sabine, Theresa Plankenhorn, and Thomas Rathgeb. 2017. «KIM-Studie: Kindheit, Internet, Medien; Basisstudie Zum Medienumgang 6- Bis 13-Jähriger in Deutschland». Stuttgart: Medienpädagogischer Forschungsverbund Südwest. https://www.mpfs.de/fileadmin/files/Studien/KIM/2016/KIM_2016_Web-PDF.pdf.

Feierabend, Sabine, Thomas Rathgeb, and Theresa Reutter. 2018. «JIM-Studie - Jugend, Information, Medien: Basisuntersuchung Zum Medienumgang 12- Bis 19-Jähriger». Stuttgart: Medienpädagogischer Forschungsverbund Südwest. https://www.mpfs.de/fileadmin/ files/Studien/JIM/2018/Studie/JIM_2018_Gesamt.pdf.

Friedrichs-Liesenkötter, Henrike, and Philip Karsch. 2018. «Smartphones im Unterricht - Wollen das Schülerinnen und Schüler überhaupt?! Eine explorative Studie zum SmartphoneEinsatz an weiterführenden Schulen aus der Sicht von Schülerinnen und Schülern». MedienPädagogik: Zeitschrift für Theorie und Praxis der Medienbildung, March, Heft 31: ‘Digitale Bildung). Medienbezogene Bildungskonzepte für die «nächste Gesellschaft>-. https://doi. org/10.21240/mpaed/31/2018.03.30.x.

Garcia, Antero. 2012. «Trust and Mobile Media Use in Schools». The Educational Forum 76 (4): 430-33. https://doi.org/10.1080/00131725.2012.707566.

Griffiths, Kate, and Maddy William. 2018. «Impact of Mobile Digital Devices in Schools». Literature review. Sydney: Centre for Education Statistics and Evaluation. https://education. nsw.gov.au/about-us/strategies-and-reports/media/documents/mobile-device-literaturereview.pdf. 
Haraway, Donna Jeanne. 1991. Simians, Cyborgs, and Women: The Reinvention of Nature. New York: Routledge.

Hepburn, Alexa. 1999. "Derrida and Psychology: Deconstruction and Its Ab/Uses in Critical and Discursive Psychologies». Theory \& Psychology 9 (5): 639-65. https://doi. org/10.1177/0959354399095004.

Ito, Mizuko, Kris Gutiérrez, Sonia Livingstone, Bill Penuel, Jean Rhodes, Katie Salen, Juliet Schor, Julian Sefton-Green, and S. Craig Watkins. 2013. Connected Learning. Cork: BookBaby.

Jandrić, Petar, Thomas Ryberg, Jeremy Knox, Nataša Lacković, Sarah Hayes, Juha Suoranta, Mark Smith, et al. 2019. "Postdigital Dialogue». Postdigital Science and Education 1 (1): 163-89. https://doi.org/10.1007/s42438-018-0011-x.

Jasanoff, Sheila, and Sang-Hyun Kim, eds. 2015. Dreamscapes of Modernity: Sociotechnical Imaginaries and the Fabrication of Power. Chicago ; London: The University of Chicago Press.

Johnson, Genevieve Marie, and Rhonda Oliver. 2014. "Small Screen Technology Use Among Indigenous Boarding School Adolescents from Remote Regions of Western Australia». The Australian Journal of Indigenous Education 43 (02): 75-84. https://doi.org/10.1017/ jie.2014.15.

Joyce-Gibbons, Andrew, David Galloway, Andrew Mollel, Sylvester Mgoma, Madeleke Pima, and Enos Deogratias. 2018. "Mobile Phone Use in Two Secondary Schools in Tanzania». Education and Information Technologies 23 (1): 73-92. https://doi.org/10.1007/s10639-0179586-1.

Katz, Raul L., Max Felix, and Madlen Gubernick. 2014. «Technology and Adolescents: Perspectives on the Things to Come». Education and Information Technologies 19 (4): 863-86.

Keengwe, Jared, Gary Schnellert, and Denise Jonas. 2014. «Mobile Phones in Education: Challenges and Opportunities for Learning». Education and Information Technologies 19 (2): 441-50. https://doi.org/10.1007/s10639-012-9235-7.

Kirschner, Paul A., and Jeroen J.G. van Merriënboer. 2013. «Do Learners Really Know Best? Urban Legends in Education». Educational Psychologist 48 (3): 169-83. https://doi.org/10. 1080/00461520.2013.804395.

KMK. 2016. «Bildung in Der Digitalen Welt. Strategie Der Kultusministerkonferenz». Kultusministerkonferenz. https://www.kmk.org/fileadmin/Dateien/pdf/PresseUndAktuelles/2017/ Strategie_neu_2017_datum_1.pdf.

Krzyżanowski, Michał. 2011. «Ethnography and Critical Discourse Analysis: Towards a Problem-Oriented Research Dialogue». Critical Discourse Studies 8 (4): 231-38. https://doi.org/ 10.1080/17405904.2011.601630.

Laclau, Ernesto, and Chantal Mouffe. 1985. Hegemony and Socialist Strategy: Towards a Radical Democratic Politics. http://rbdigital.oneclickdigital.com.

Lee, Mal, and Roger Broadie. 2016. A Taxonomy of School Evolutionary Changes. Australia: Douglas and Brown. 
Livingstone, Sonia M., and Julian Sefton-Green. 2016. The Class: Living and Learning in the Digital Age. Connected Youth and Digital Futures. New York: New York University Press. http:// connectedyouth.nyupress.org/book/9781479824243/.

Macgilchrist, Felicitas. 2017. Die medialen Subjekte des 21. Jahrhunderts: Digitale Kompetenzen und/oder Critical Digital Citizenship. In Heidrun Allert, Christoph Richter \& Michael Asmussen (Eds.), Digitalität und Selbst: Interdisziplinäre Perspektiven auf Subjektivierungsund Bildungsprozesse, (145-168). Bielefeld: transcript.

Macgilchrist, Felicitas. 2019. «Digitale Bildungsmedien im Diskurs. Wertesysteme, Wirkkraft und alternative Konzepte |APuZ». Aus Politik und Zeitgeschichte 69 (27-28): 18-23.

Macgilchrist, Felicitas, Marion Ott, and Antje Langer. 2014. «Der Praktische Vollzug von »Bologna«Eine Ethnographische Diskursanalyse». In Diskursforschung, edited by Johannes Angermuller, Martin Nonhoff, Eva Herschinger, Felicitas Macgilchrist, Martin Reisigl, Juliette Wedl, Daniel Wrana, and Alexander Ziem. Bielefeld: transcript Verlag. https://doi. org/10.14361/transcript.9783839427224.725.

Macgilchrist, Felicitas, and Tom Van Hout. 2011. «Ethnographic Discourse Analysis and Social Science». Forum Qualitative Sozialforschung / Forum: Qualitative Social Research Vol 12 (January): No 1 (2011): The KWALON Experiment: Discussions on Qualitative Data Analysis Software by Developers and Users-. https://doi.org/10.17169/fqs-12.1.1600.

McKnight, Katherine, Kimberly O’Malley, Roxanne Ruzic, Maria Kelly Horsley, John J. Franey, and Katherine Bassett. 2016. "Teaching in a Digital Age: How Educators Use Technology to Improve Student Learning». Journal of Research on Technology in Education 48 (3): 194211. https://doi.org/10.1080/15391523.2016.1175856.

Mohn, Elisabeth, and Klaus Amann. 2006. «Lernkörper - kamera-ethnographische Studien zum Schülerjob». IWF Wissen und Medien.

Nuray Zan. 2015. "The Effects of Smartphone Use on Organic Chemical Compound Learning». US-China Education Review A 5 (2). https://doi.org/10.17265/2161-623X/2015.02.003.

OECD. 2015. Students, Computers and Learning: Making the Connection. PISA. OECD. https:// doi.org/10.1787/9789264239555-en.

Ólafsson, Kjartan, Sonia Livingston, Leslie Haddon, and with members from the EU Kids Online Network. 2014. "Children's Use of Online Technologies in Europe. A Review of the European Evidence Base.» London: LSE. https://www.dependencias.pt/ficheiros/conteudos/ files/Children.pdf.

O’Mara, Ben, and Anne Harris. 2016. «Intercultural Crossings in a Digital Age: ICT Pathways with Migrant and Refugee-Background Youth». Race Ethnicity and Education 19 (3): 639-58. https://doi.org/10.1080/13613324.2014.885418.

Ott, Torbjörn, Anita Grigic Magnusson, Alexandra Weilenmann, and Ylva Hård af Segerstad. 2018. "It Must Not Disturb, It's as Simple as That": Students' Voices on Mobile Phones in the Infrastructure for Learning in Swedish Upper Secondary School». Education and Information Technologies 23 (1): 517-36. https://doi.org/10.1007/s10639-017-9615-0. 
Pimmer, Christoph. 2016. «Mobile Learning as Boundary Crossing: An Alternative Route to Technology-Enhanced Learning?» Interactive Learning Environments 24 (5): 979-90. https://doi.org/10.1080/10494820.2015.1128211.

Puentedura, Ruben R. 2012. «Building Upon SAMR». http://www.hippasus.com/rrpweblog/archives/2012/09/03/BuildingUponSAMR.pdf.

Ranieri, M., and I. Bruni. 2013. «Empowering Creativity in Young People Through Mobile Learning: An Investigation of Creative Practices of Mobile Media Uses In and Out of School». International Journal of Mobile and Blended Learning 5 (3): 17-33. https://doi.org/10.4018/ jmbl.2013070102.

Schatzki, Theodore R. 2008. Social Practices: A Wittgensteinian Approach to Human Activity and the Social. Digitally printed version, Paperback re-Issue. Cambridge: Cambridge University Press.

Selwyn, Neil. 2009. «The Digital Native - Myth and Reality». Aslib Proceedings 61 (4): 364-79. https://doi.org/10.1108/00012530910973776.

Selwyn, Neil, Selena Nemori, Scott Bulfin, and Nicola F. Johnson. 2018. Everyday Schooling in the Digital Age: High School, High Tech? Abingdon, Oxon ; New York, NY: Routledge.

Sims, Christo. 2014. «From Differentiated Use to Differentiating Practices: Negotiating Legitimate Participation and the Production of Privileged Identities». Information, Communication \& Society 17 (6): 670-82. https://doi.org/10.1080/1369118X.2013.808363.

Sims, Christo. 2018. Disruptive Fixation: School Reform and the Pitfalls of Techno-Idealism. http://dx.doi.org/10.23943/princeton/9780691163987.001.0001.

Sung, Yao-Ting, Kuo-En Chang, and Tzu-Chien Liu. 2016. «The Effects of Integrating Mobile Devices with Teaching and Learning on Students' Learning Performance: A Meta-Analysis and Research Synthesis». Computers \& Education 94 (March): 252-75. https://doi.org/10.1016/j. compedu.2015.11.008.

Szakács-Behling, S., A. Bock, C. I. Keßler, F. Macgilchrist, and R. Spielhaus (forthcoming 2020): "Global Citizenship in motion: Comparing Cross-Border Practices in German Schools Abroad». In Identities and education: Comparative perspectives in times of crisis, edited by Klerides E. and S. Carney. London: Bloomsbury.

Taffel, Sy. 2016. «Perspectives on the Postdigital: Beyond Rhetorics of Progress and Novelty». Convergence: The International Journal of Research into New Media Technologies 22 (3): 324-38. https://doi.org/10.1177/1354856514567827.

Thomas, Kevin, and Marco A. Muñoz. 2016. «Hold the Phone! High School Students' Perceptions of Mobile Phone Integration in the Classroom». American Secondary Education 44 (3): $19-37$.

Twenge, Jean M. 2018. Me, my selfie and I: was Jugendliche heute wirklich bewegt. Translated by Nikolaus de Palézieux. 1. Auflage, deutsche Erstausgabe. München: Mosaik.

Watters, Audrey. 2017. «The Weaponization of Education Data». Hack Education (blog). 2017. http://hackeducation.com/2017/12/11/top-ed-tech-trends-weaponized-data. 
Wiesemann, J, and I Fürtig. 2018. «Kindheit Zwischen Smartphone Und Pädagogischem Schulalltag». In Institutionalisierungen von Kindheit: Childhood Studies Zwischen Soziologie Und Erziehungswissenschaft, edited by Tanja Betz, Sabine Bollig, Magdalena Joos, and Sascha Neumann, 1. Auflage, 196-212. Kindheiten. Weinheim: Beltz Juventa.

Williamson, Ben. 2018. Big Data in Education: The Digital Future of Learning, Policy and Practice. 1st edition. Thousand Oaks, CA: SAGE Publications.

Wrana, Daniel, and Antje Langer. 2007. «An den Rändern der Diskurse. Jenseits der Unterscheidung diskursiver und nicht-diskursiver Praktiken». Forum Qualitative Sozialforschung / Forum: Qualitative Social Research Vol 8 (May): No 2 (2007): From Michel Foucault's Theory of Discourse to Empirical Discourse Research-. https://doi.org/10.17169/fqs-8.2.253.

Wu, Wen-Hsiung, Yen-Chun Jim Wu, Chun-Yu Chen, Hao-Yun Kao, Che-Hung Lin, and Sih-Han Huang. 2012. «Review of Trends from Mobile Learning Studies: A Meta-Analysis». Computers \& Education 59 (2): 817-27. https://doi.org/10.1016/j.compedu.2012.03.016.

\section{Acknowledgements}

This research was funded by the German Foreign Ministry (Auswärtiges Amt). We thank all the participating schools for welcoming us and making time for our observations and questions. We thank Johanna Ahlrichs for her role in generating and analyzing data from the Yellow and Blue schools. 